\title{
Serum Uric Acid Level and Cardiovascular Disease Development Risk in Stage 3-5 Chronic Kidney Disease Patients
}

\author{
Evre 3-5 Kronik Böbrek Hastalarında Serum Ürik Asit Seviyesi ve Kardiyovasküler Hastalık \\ Gelişim Riski
}

\section{Süleyman KARAKÖSE \\ (D) 0000-0003-4680-7435}

Konya Training and Research Hospital Department of Nephrology, Konya, Turkey

\section{Corresponding Author Sorumlu Yazar}

Süleyman KARAKÖSE

suleymankarakose@yahoo.com

Received / Geliş Tarihi : 11.07.2020 Accepted / Kabul Tarihi : 20.10.2020 Available Online /

Çevrimiçi Yayın Tarihi : 25.12.2020

\begin{abstract}
Aim: The patients with chronic kidney disease (CKD) have higher risk of cardiovascular disease (CVD) than the general population and this risk increases in advanced CKD stages. The data about the association between CVD and uric acid level in stage 3-5 CKD patients are limited in the literature. The aim of this study is to investigate whether uric acid levels are associated with cardiovascular events and mortality in the CKD patients.

Material and Methods: Patients who were followed up with the diagnosis of stage 3-5 CKD between June 2014 and December 2019 were evaluated retrospectively. A hundred stage 3-5 CKD cases above the age of eighteen were included in the study. The patients were divided into two groups according to average serum uric acid levels; $<7 \mathrm{mg} / \mathrm{dL}$ and $\geq 7 \mathrm{mg} / \mathrm{dL}$. Any confirmed diagnosis of stroke, myocardial infarction, coronary heart disease or heart failure was accepted positive for the history of CVD.

Results: Cardiovascular event development was observed in 15 patients and mortality in 1 patient. CVD were seen in $10(21.3 \%)$ patients in group 1 while $5(9.4 \%)$ patients in group 2. Although the cardiovascular events were seen more in the group 1, this difference was not statistically significant $(\mathrm{p}=0.098)$.

Conclusion: Although CVD is seen higher in the low uric acid $(<7 \mathrm{mg} / \mathrm{dL})$ group, no significant association was found between serum uric acid level and development of CVD in stage 3-5 CKD patients, in this study. Prospective studies with larger sample sizes may provide better evidence regarding possible relationship.

Keywords: Hyperuricemia; chronic kidney disease; cardiovascular disease.
\end{abstract}

\section{ÖZ}

Amaç: Kronik böbrek hastalığı $(\mathrm{KBH})$ olanlarda kardiyovasküler hastalık (KVH) riski genel popülasyondan daha yüksektir ve bu risk ileri KBH evrelerinde artmaktadır. Evre 3-5 KBH hastalarında KVH ve ürik asit seviyesi arasındaki ilişki hakkındaki veriler literatürde sınırlıdır. $\mathrm{Bu}$ çalışmanın amacı, KBH hastalarında ürik asit düzeyinin kardiyovasküler olaylar ve mortalite ile ilişkili olup olmadığının incelenmesidir.

Gereç ve Yöntemler: Haziran 2014 ve Aralık 2019 tarihleri arasında evre 3-5 KBH tanısı ile takip edilen hastalar geriye dönük olarak değerlendirildi. On sekiz yaş üstü 100 evre 3-5 KBH olgusu çalışmaya dahil edildi. Hastalar ortalama serum ürik asit düzeylerine göre $<7 \mathrm{mg} / \mathrm{dL}$ ve $\geq 7 \mathrm{mg} / \mathrm{dL}$ olmak üzere iki gruba ayrıldı. Doğrulanmış inme, miyokard enfarktüsü, koroner kalp hastalığı veya kalp yetmezliği tanısı olması KVH öyküsü için pozitif kabul edildi.

Bulgular: On beș hastada kardiyovasküler olay gelișimi, 1 hastada mortalite izlendi. Grup 1'deki $10(\% 21,3)$ hastada ve grup 2'deki $5(\% 9,4)$ hastada KVH görüldü. Grup 1'de kardiyovasküler olaylar daha fazla görülmesine rağmen, bu fark istatistiksel olarak anlamlı değildi $(\mathrm{p}=0.098)$.

Sonuç: Bu çalışmada, düşük ürik asit $(<7 \mathrm{mg} / \mathrm{dL})$ grubunda $\mathrm{KVH}$ daha yüksek görülmekle birlikte, evre 3-5 KBH hastalarında serum ürik asit düzeyi ile KVH gelişimi arasında anlamlı bir ilişki bulunamamıştır. Daha fazla örneklem büyüklükleri ile ileriye dönük çalışmalar, olası ilişki hakkında daha iyi kanıt sağlayabilir.

Anahtar kelimeler: Hiperürisemi; kronik böbrek hastalığı; kardiyovasküler hastalık. 


\section{INTRODUCTION}

Chronic kidney disease (CKD) is an important health problem all over the world (1). The patients with CKD have higher risk of cardiovascular disease (CVD) than the general population and this risk increases in advanced CKD stages (2). Hypertension, smoking, diabetes, hyperlipidemia and high serum uric acid levels are the examples of traditional risk factors for CVD. The end product of purine metabolism is uric acid. Uric acid have some roles in formation of free radicals (3), platelet adhesiveness $(4,5)$, and oxidative stress (6). A relationship between uric acid and CVD in the general population have been reported by a few studies (7-10) but not by other studies (11-14). And also there are studies reporting that lower uric acid levels were associated with mortality $(15,16)$. Therefore, there are conflicting results about the association between serum uric acid levels and cardiovascular disease or all-cause mortality.

Urinary excretion of uric acid is decreased in chronic renal disease and as a result of this, serum uric acid levels are generally higher in CKD patients than the general population (17). The data about the association between CVD and uric acid level in stage 3-5 CKD patients are limited in the literature. Weiner et al. (18) reported that uric acid was not an independent predictor of a composite outcome of myocardial infarction, stroke, and all-cause mortality in stage 3-5 CKD patients. On the other hand, a relationship between uric acid and cardiovascular mortality has been shown by two studies $(19,20)$. There are conflicting data in the literature about hyperuricemia and cardiovascular events in CKD patients. We therefore aimed to investigate whether uric acid levels are associated with adverse CVD and mortality in the CKD patients.

\section{MATERIAL AND METHODS}

The files of patients who were followed up with the diagnosis of stage 3-5 CKD between June 2014 and December 2019 were evaluated retrospectively. The ethics committee of Necmettin Erbakan University, Faculty of Medicine approved the study protocol (2020/2788, 21.08.2020). A hundred stage 3-5 CKD cases above the age of eighteen were included in the study. The patients who needed renal replacement treatment were excluded from the study. Patients with hyperuricemia-related disease such as gout, malignancy and at the beginning using a uric acid lowering therapy were excluded from the study. The Modification of Diet in Renal Disease (MDRD) formula, eGFR $=175 \times$ creatinine $^{-1.154} \times$ age $^{-0.203} \times 1.212$ (if black) $\times 0.742$ (if female), was used to calculate the eGFR (21). Early morning spot urine protein-creatinine ratio was used to detect the daily protein loss. Any confirmed diagnosis of stroke, myocardial infarction, coronary heart disease or heart failure was accepted positive for the history of CVD. The average of three separate serum uric acid value (at least 6 months between the samples) of patients during the follow-up period was taken. The patients were divided into two groups according to the average serum uric acid levels; first group consists of the patients who had average serum uric acid below 7 $\mathrm{mg} / \mathrm{dl}$ and second group consists of the patients who had higher than $7 \mathrm{mg} / \mathrm{dl}$ average serum uric acid (22). We investigated whether there was any difference in terms of cardiovascular event and mortality according to uric acid level during the follow-up period.

\section{Statistical Analysis}

Statistical analysis was performed with the SPSS v.22 statistical software. The normality of the variables was determined with Kolmogorov-Smirnov test. Descriptive statistics for were given as mean \pm standard deviation, and median, minimum-maximum with interquartile range according to the distribution of the variable. The groups were compared with the independent samples $t$ test or Mann-Whitney U test, as appropriate. Categorical variables were analyzed by Pearson chi-square test or Fisher's exact test, and given as frequency and percentage. A $p$ value of $<0.05$ was considered statistically significant.

\section{RESULTS}

The study included 100 stage 3-5 CKD patients (53 females, 47 males) with a mean age of $59.7 \pm 14.3$ years. The mean follow-up was $33.1 \pm 8.4$ (median=31.5, range, 18-49) months. Baseline characteristics of patients are summarized in Table 1. The number of patients with a history of hypertension was 92, diabetes mellitus was 38, glomerulonephritis was 15 , polycystic kidney disease was 5 and amyloidosis was 3 . Twenty six patients had previous cardiovascular disease history. CVD development was observed in 15 patients and mortality in 1 patient in follow up period. Out of 100 patients, 83 were using ACE inhibitors or ARBs and 55 were using diuretics.

Patients were divided into two groups according to uric acid levels (group 1: uric acid $<7 \mathrm{mg} / \mathrm{dL}$ and group 2: uric acid $\geq 7 \mathrm{mg} / \mathrm{dL}$ ). The mean age of group 1 was $59.9 \pm 15.3$, the mean age of group 2 was $59.9 \pm 13.5$ years. Gender distribution of groups were as follows; in group 1 there were $23(48.9 \%)$ male and $24(51.1 \%)$ female, and in group 2 there were $24(45.3 \%)$ male and $29(54.7 \%)$ female. The mean follow-up time of group 1 was $33.9 \pm 8.2$ months, and group 2 was $32.4 \pm 8.6$ months. There were no difference between the two groups in terms of gender, age, and follow up time $(\mathrm{p}=0.715, \mathrm{p}=0.916, \mathrm{p}=0.381$, respectively). Demographic and laboratory parameters by groups according to the uric acid levels were shown in Table 2.

There were no difference between groups in terms of comorbidities and frequency of use of ACE inhibitors, ARBs and diuretics (Table 3). CVD were seen in 10 $(21.3 \%)$ patients in group 1 while in $5(9.4 \%)$ patients in group 2. Although the cardiovascular events were seen more in the group with low uric acid, this difference was not statistically significant $(\mathrm{p}=0.098)$.

Table 1. Baseline characteristics of patients $(n=100)$

\begin{tabular}{lc}
\hline Age (years) & $59.7 \pm 14.3$ \\
BMI $\left(\mathrm{kg} / \mathrm{m}^{2}\right)$ & $28.1 \pm 3.4$ \\
Uric acid $(\mathrm{mg} / \mathrm{dL})$ & $7.1 \pm 1.4$ \\
Creatinine $(\mathrm{mg} / \mathrm{dL})$ & $2.1 \pm 0.9$ \\
eGFR $(\mathrm{mL} / \mathrm{min} / 1.73 \mathrm{~m} 2)$ & $33.3 \pm 14.2$ \\
Albumin $(\mathrm{g} / \mathrm{dL})$ & $4.2 \pm 0.5$ \\
Hemoglobin $(\mathrm{g} / \mathrm{dL})$ & $12.9 \pm 1.6$ \\
Calcium $(\mathrm{mg} / \mathrm{dL})$ & $9.3 \pm 0.7$ \\
Phosphorus (mg/dL) & $4.6 \pm 0.6$ \\
PTH (pg/mL) & $132.4 \pm 89.1$ \\
Spot urine protein/creatinine* & 594 (1496) [1.49-15078] \\
\hline BMI: body mass index, eGFR: estimated glomerular filtration rate, PTH: \\
parathyroid hormone, *: median (interquartile range) [minimum-maximum]
\end{tabular}


Table 2. Demographic and laboratory parameters of patients by uric acid groups

\begin{tabular}{|c|c|c|c|}
\hline & Group $1(n=47)$ & Group $2(n=53)$ & $\mathbf{p}$ \\
\hline Age (years) & $59.9 \pm 15.3$ & $59.9 \pm 13.5$ & 0.916 \\
\hline BMI $\left(\mathrm{kg} / \mathrm{m}^{2}\right)$ & $27.9 \pm 3.4$ & $28.1 \pm 3.5$ & 0.753 \\
\hline Follow-up time (months) & $33.9 \pm 8.2$ & $32.4 \pm 8.6$ & 0.381 \\
\hline Uric acid, (mg/dL) & $6.0 \pm 0.8$ & $8.1 \pm 0.9$ & $<0.001$ \\
\hline Creatinine (mg/dL) & $2.0 \pm 0.8$ & $2.1 \pm 0.9$ & 0.448 \\
\hline eGFR (mL/min/1.73 m2) & $35.5 \pm 14.8$ & $31.7 \pm 13.4$ & 0.157 \\
\hline Albumin (g/dL) & $4.2 \pm 0.5$ & $4.1 \pm 0.5$ & 0.373 \\
\hline Hemoglobin (g/dL) & $13.1 \pm 1.5$ & $12.8 \pm 1.7$ & 0.298 \\
\hline Calcium (mg/dL) & $9.2 \pm 0.8$ & $9.4 \pm 0.7$ & 0.292 \\
\hline Phosphorus (mg/dL) & $4.6 \pm 0.6$ & $4.7 \pm 0.6$ & 0.282 \\
\hline PTH (pg/mL) & $86(90)$ [21-385] & $123(100)$ [39-457] & 0.003 \\
\hline Spot urine protein/creatinine & $524(1251)$ [1.49-6836] & $620(1657)$ [22-15078] & 0.236 \\
\hline
\end{tabular}

Table 3. Characteristics of patients by uric acid groups

\begin{tabular}{lccc}
\hline & $\begin{array}{c}\text { Group 1 } \\
(\mathbf{n = 4 7})\end{array}$ & $\begin{array}{c}\text { Group 2 } \\
(\mathbf{n = 5 3})\end{array}$ & $\mathbf{p}$ \\
\hline Comorbidities & & & \\
$\quad$ Hypertension & $45(95.7)$ & $47(88.7)$ & 0.276 \\
$\quad$ Diabetes mellitus & $20(42.6)$ & $18(34.0)$ & 0.377 \\
$\quad$ Glomerulonephritis & $5(10.6)$ & $10(18.9)$ & 0.250 \\
$\quad$ Polycystic kidney disease & $0(0.0)$ & $5(9.4)$ & 0.058 \\
$\quad$ Amyloidosis & $0(0.0)$ & $3(5.7)$ & 0.245 \\
Medications & & & \\
$\quad$ ACE inhibitors and ARBs & $38(80.9)$ & $45(84.9)$ & 0.590 \\
$\quad$ Diuretics & $29(61.7)$ & $26(49.1)$ & 0.205 \\
Cardiovascular Event & $10(21.3)$ & $5(9.4)$ & 0.098 \\
\hline ACE: angiotensin-converting enzyme, ARBs: angiotensin II receptor blockers
\end{tabular}

\section{DISCUSSION}

Based on our study results there is no meaningful relationship between serum uric acid levels and cardiovascular event in CKD patients. There are prospective studies reporting that there is a relationship between basal hyperuricemia and the development of cardiovascular event and mortality $(16,23)$. Although there are data reported in this direction in the literature but uric acid has not been identified as a causal risk factor for CVD. On the other hand it's reported that there are important links between uric acid and diseases which are known to be associated with the development of cardiovascular events, such as hypertension, impaired glucose metabolism and dyslipidemia $(13,15)$. Therefore, it may be a more correct approach to evaluate uric acid as a risk marker for the development of CVD.

Although it is not statistically significant level, we found that the cardiovascular events development risk was higher in those with low uric acid levels. Gerber et al. (15) reported that the development of cardiovascular events was higher in those with low uric acid levels. Li et al. (24) and Dong et al. (25) reported in their study that hemodialysis patients with low uric acid levels were associated with high risk for cardiovascular mortality and all-cause mortality. Aker Karagöz et al. (26) reported that there was no relationship between uric acid level and the development of CVD in hypertensive patients. In another study conducted by Shao et al. (27), there was no significant relationship between uric acid level and coronary heart disease in type 2 diabetes patients.

Some researchers reported the combined results for female and male patients after correction for sex while others preferred sex specific investigation in uric acid studies $(13,16)$. Since serum uric acid level in males is higher than females, we think that gender-specific analyzes are required in studies related to uric acid. In our study, there were $23(48.9 \%)$ males and $24(51.1 \%)$ females in the low uric acid group whereas $24(45.3 \%)$ males and $29(54.7 \%)$ females in the high uric acid group. There was no difference in terms of gender distribution between the two groups. When we included all cases (53 females, 47 males) the uric acid averages of females and males were found

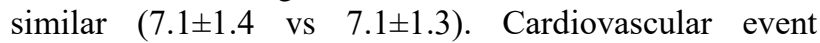
development rate was similar in males and females.

The fact that studies have very different results might depend on differences in patient populations, different follow-up times and statistical regulations. While other studies examined the development of cardiovascular events over a single basal uric acid value, but we evaluated the cardiovascular event development rate with the average of three uric acid samples taken at different times during the follow-up period. In this way, we think that we made a more accurate assessment for the patients with a low serum uric acid level at the beginning and raised later, and also for the patients that had a high level of uric acid at the beginning and fall down later. We think that examinations based on a single value could be misleading. In conclusion, although CVD is seen higher in stage 3-5 CKD patients with low uric acid levels, no significant association was found between serum uric acid level and development of CVD. Detailed prospective studies with huge number of patients and longer follow up time are required to comment the possible relationship.

Ethics Committee Approval: The study was approved by the Ethics Committee of Necmettin Erbakan University Meram Faculty of Medicine (21.08.2020, 2020/2788).

Conflict of Interest: None declared by the authors.

Financial Disclosure: None declared by the authors.

Acknowledgements: None declared by the authors. 


\section{REFERENCES}

1. Kasahara M, Kuwabara Y, Moriyama T, Tanabe K, Satoh-Asahara N, Katsuya T, et al. Intensive uric acidlowering therapy in CKD patients: the protocol for a randomized controlled trial. Clin Exp Nephrol. 2020;24(3):235-41.

2. Tanaka K, Watanabe T, Takeuchi A, Ohashi Y, Nitta $\mathrm{K}$, Akizawa T, et al. Cardiovascular events and death in Japanese patients with chronic kidney disease. Kidney Int. 2017;91(1):227-34.

3. Vásquez-Vivar J, Santos AM, Junqueira VB, Augusto O. Peroxynitrite-mediated formation of free radicals in human plasma: EPR detection of ascorbyl, albuminthiyl and uric acid-derived free radicals. Biochem J. 1996;314(Pt 3):869-76.

4. Emmerson BT. Atherosclerosis and urate metabolism. Aust N Z J Med. 1979;9(4):451-4.

5. Ginsberg MH, Kozin F, O’Malley M, McCarty DJ. Release of platelet constituents by monosodium urate crystals. J Clin Invest. 1977;60(5):999-1007.

6. Leyva F, Anker S, Swan JW, Godsland IF, Wingrove CS, Chua TP, et al. Serum uric acid as an index of impaired oxidative metabolism in chronic heart failure. Eur Heart J. 1997;18(5):858-65.

7. Liese AD, Hense HW, Löwel H, Döring A, Tietze M, Keil U. Association of serum uric acid with all-cause and cardiovascular disease mortality and incident myocardial infarction in the MONICA Augsburg cohort. World Health Organization Monitoring Trends and Determinants in Cardiovascular Diseases. Epidemiology 1999;10(4):391-7.

8. Bengtsson C, Lapidus L, Stendahl C, Waldenström J. Hyperuricaemia and risk of cardiovascular disease and overall death. A 12-year follow-up of participants in the population study of women in Gothenburg, Sweden. Acta Med Scand 1988;224(6):549-55.

9. Fang J, Alderman MH. Serum uric acid and cardiovascular mortality the NHANES I epidemiologic follow-up study, 1971-1992. National Health and Nutrition Examination Survey. JAMA. 2000;283(18):2404-10.

10. Casiglia E, Spolaore P, Ginocchio G, Colangeli G, Di Menza G, Marchioro M, et al. Predictors of mortality in very old subjects aged 80 years or over. Eur J Epidemiol 1993;9(6):577-86.

11. Wannamethee SG, Shaper AG, Whincup PH. Serum urate and the risk of major coronary heart disease events. Heart. 1997;78(2):147-53.

12. Moriarity JT, Folsom AR, Iribarren C, Nieto FJ, Rosamond WD. Serum uric acid and risk of coronary heart disease: Atherosclerosis Risk in Communities (ARIC) Study. Ann Epidemiol. 2000;10(3):136-43.

13. Culleton BF, Larson MG, Kannel WB, Levy D. Serum uric acid and risk for cardiovascular disease and death: the Framingham Heart Study. Ann Intern Med. 1999;131(1):7-13.

14. Reunanen A, Takkunen H, Knekt P, Aromaa A.
Hyperuricemia as a risk factor for cardiovascular mortality. Acta Med Scand Suppl. 1982;668:49-59.

15. Gerber Y, Tanne D, Medalie JH, Goldbourt U. Serum uric acid and long-term mortality from stroke, coronary heart disease and all causes. Eur J Cardiovasc Prev Rehabil. 2006;13(2):193-8.

16. Zhao G, Huang L, Song M, Song Y. Baseline serum uric acid level as a predictor of cardiovascular disease related mortality and all-cause mortality: A metaanalysis of prospective studies. Atherosclerosis. 2013;231(1):61-8.

17. Edwards NL. The role of hyperuricemia and gout in kidney and cardiovascular disease. Clev Clin J Med. 2008;75(Suppl 5):S13-6.

18. Weiner DE, Tighiouart H, Elsayed EF, Griffith JL, Salem DN, Levey AS, et al. The relationship between nontraditional risk factors and outcomes in individuals with stage 3 to 4 CKD. Am J Kidney Dis. 2008;51(2):212-23.

19. Madero M, Sarnak MJ, Wang X, Greene T, Beck GJ, Kusek JW, et al. Uric acid and long-term outcomes in CKD. Am J Kidney Dis. 2009;53(5):796-803.

20. Suliman ME, Johnson RJ, García-López E, Qureshi AR, Molinaei H, Carrero JJ, et al. J-shaped mortality relationship for uric acid in CKD. Am J Kidney Dis. 2006;48(5):761-71.

21. Levey AS, Coresh J, Greene T, Stevens LA, Zhang YL, Hendriksen S, et al. Using standardized serum creatinine values in the modification of diet in renal disease study equation for estimating glomerular filtration rate. Ann Intern Med. 2006;145(4):247-54.

22. Chapter 3: Management of progression and complications of CKD. Kidney Int Suppl. 2013;3(1):73-90.

23. Niskanen LK, Laaksonen DE, Nyyssönen K, Alfthan G, Lakka HM, Lakka TA, et al. Uric acid level as a risk factor for cardiovascular and all-cause mortality in middle-aged men: a prospective cohort study. Arch Intern Med. 2004;164(14):1546-51.

24. Li M, Ye ZC, Li CM, Zhao WB, Tang H, Liu X, et al. Low serum uric acid levels increase the risk of allcause death and cardiovascular death in hemodialysis patients. Ren Fail. 2020;42(1):315-22.

25. Dong ZX, Tian M, Li H, Wu Y, Du XG, Dong JW, et al. Association of serum uric acid concentration and its change with cardiovascular death and all-cause mortality. Dis Markers. 2020;2020:7646384.

26. Aker Karagöz Y, Şahin İ, Karagöz F, Şit D. Evaluation of relationship between uric acid and CRP, RDW, and MPV as cardiovascular risk factors in patients with hypertension. Bezmialem Science. 2017;5(1):16-21.

27. Shao, Shao H, Sawhney MS, Shi L. Serum uric acid as a risk factor of all-cause mortality and cardiovascular events among type 2 diabetes population: Meta analysis of correlational evidence. J Diabetes Complications 2019;33(10):107409. 